\title{
FACTORS AFFECTING ADHERENCE TO ANTIRETROVIRUS THERAPY IN HIV/AIDS PATIENTS IN YOGYAKARTA
}

\author{
Yelli Yani Rusyani \\ Universitas Respati Yogyakarta
}

\begin{abstract}
Background: Treatment adherence is an important issue in HIV/AIDS control. Adherence to HIV/AIDS treatment includes initiating care with an HIV provider (linkage to care), regular attendance in appointments (retention in care), and adherence to antiretroviral therapy (ART). Adherence to each step in the continuum of care is critical to achieve optimal clinical outcomes of ART and to realize the potential public health benefit of treatment as prevention. This study aimed to examine factors affecting adherence to ART in HIV/AIDS patients.

Subjects and Method: This was a cross-sectional study conducted at Victory Plus non-government organization (NGO), Yogyakarta. A sample of 210 HIV/AIDS patients undertaking ART at the NGO was selected for this study. The dependent variable was adherence to ART. The independent variables were knowledge, attitude, and motivation. The data were collected by questionnaire and analyzed by a multiple linear regression.

Results: Mean age of HIV/AIDS patients was 36 years. Mean duration of treatment was 5.5 months. Mean knowledge in HIV/AIDS, attitude, and motivation was $78.3(\mathrm{SD}=10.5), 80.6(\mathrm{SD}=4.4)$, and $50.9(\mathrm{SD}=16.8)$, respectively. Adherence to ART was positively affected by better knowledge in HIV/AIDS ( $b=$ $2.91 ; 95 \% \mathrm{CI}=1.15$ to $5.21 ; \mathrm{p}=0.014)$, positive attitude $(\mathrm{b}=1.23 ; 95 \% \mathrm{CI}=1.06$ to $3.31 ; \mathrm{p}=0.048)$, and strong motivation $(\mathrm{b}=2.01$; CI $95 \%=0.91$ to $4.01 ; \mathrm{p}=$ $0.038)$.
\end{abstract}

Conclusion: Better knowledge, positive attitude, and strong motivation, affect the adherence to ART.

Keywords: HIV/AIDS, adherence, knowledge, attitude, motivation

\section{Correspondence:}

Yelli Yani Rusyani. Universitas Respati Yogyakarta.

Email: yellirusyani@gmail.com. Mobile: 081393541969 